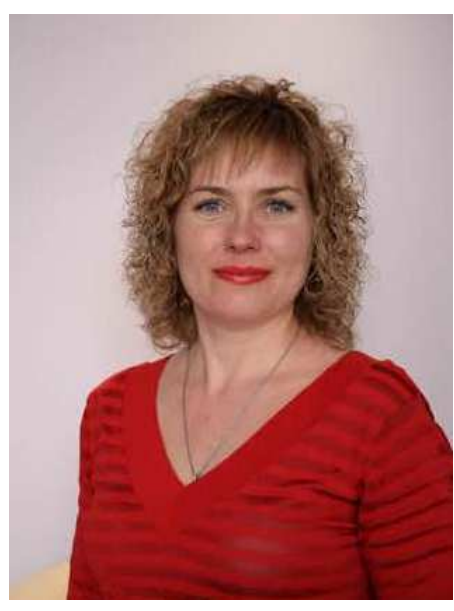

Роженко Олександра Вікторівна, кандидат економічних наук Донецький юридичний інститут МВС України, м. Кривий Ріг) ORCID: https://orcid.org/0000-0002-9358-5436

\title{
ПРАВОВЕ РЕГУЛЮВАННЯ СТРАХУВАННЯ ІНВЕСТИЦІЙ В УКРАЇНІ
}

У статті досліджено тенденції розвитку інвестиційної діяльності в Україні, здійснено аналіз стану й розвитку ринку України з видів страхування, інших, ніж страхування життя; установлено взаємозв'язок видів захисту суб'єктів інвестиційної діяльності. Запропоновано вдосконалення механізму правового регулювання страхування інвестицій в Україні в розрізі прямих $і$ капітальних інвестицій, який включає, відповідно, дозвільні й зобов'язувальні норми права.

Ключові слова: страхування; правове регулювання; інвестиції; ефрективність; динаміка розвитку; механізм.

Постановка проблеми. Траєкторію розвитку сучасної України визначено Національною доповіддю 2017 «Цілі сталого розвитку: Україна» [1], у якій визначено майбутні вектори руху, адаптовані для України на період до 2030 року, першочергові пріоритети й індикатори відповідних соціально-економічних, організаційних, політико-правових умов тощо. Джерелом усіх 17 цілей сталого розвитку України $є$ залучення інвестицій як засобу необхідних перетворень і розвитку соціально-економічної системи держави. Вітчизняні макроекономічні та мікроекономічні умови господарювання сьогодні формують для ведення інвестиційної діяльності надмірні ризики, що є причиною зниження бізнес-активності в зазначеній сфері.

Для підтвердження актуальності та значущості поставленої проблеми проведено дослідження динаміки прямих та капітальних інвестицій у національній економіці України за період 2014-2018 рр., що графічно наведено на рисунку 1.

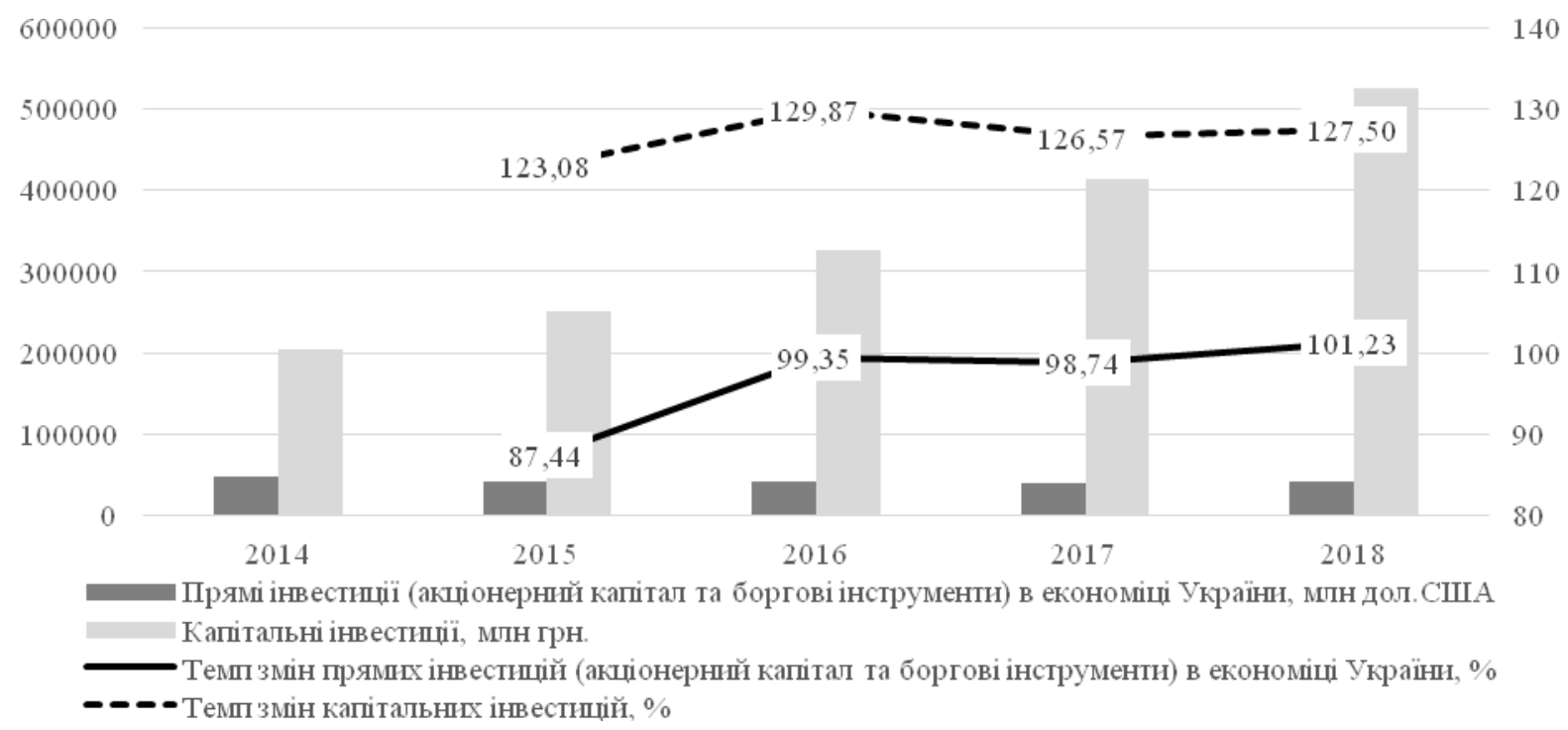


Рисунок 1. Динаміка прямих та капітальних інвестицій в економіці України за 20142018 pp. [2; 3$]$

Прямі інвестиції в економіці України здебільшого не мали суттєвої динаміки, що демонструє їхній темп зростання - близько $100 \%$, окрім 2015 року, у якому вони знизилися на 12,56 \%. На відміну від прямих, капітальні інвестиції щороку зростали майже на 30 \%. Виявлені тенденції підтверджують необхідність активізації розвитку інвестиційної діяльності в напрямку прямих інвестицій та більш глибокого аналізу динаміки капітальних інвестицій, що наведено на рисунку 2.

Як видно з проведеного аналізу динаміки капітальних інвестицій за видами економічної діяльності та джерелами фінансування, близько 70 \% усіх капітальних інвестицій в Україні здійснено за КВЕД В $+\mathrm{C}+\mathrm{D}+\mathrm{E}$ «Промисловість». Більше $30 \%$ капітальних інвестицій у державі здійснено за рахунок власних коштів підприємств та організацій. Але не виявлено закономірності між стабільним зростанням динаміки сум капітальних інвестицій, які переважно вкладені в промисловість, та рентабельністю промислових підприємств, що має як позитивні, так і негативні тенденції за досліджуваний період.

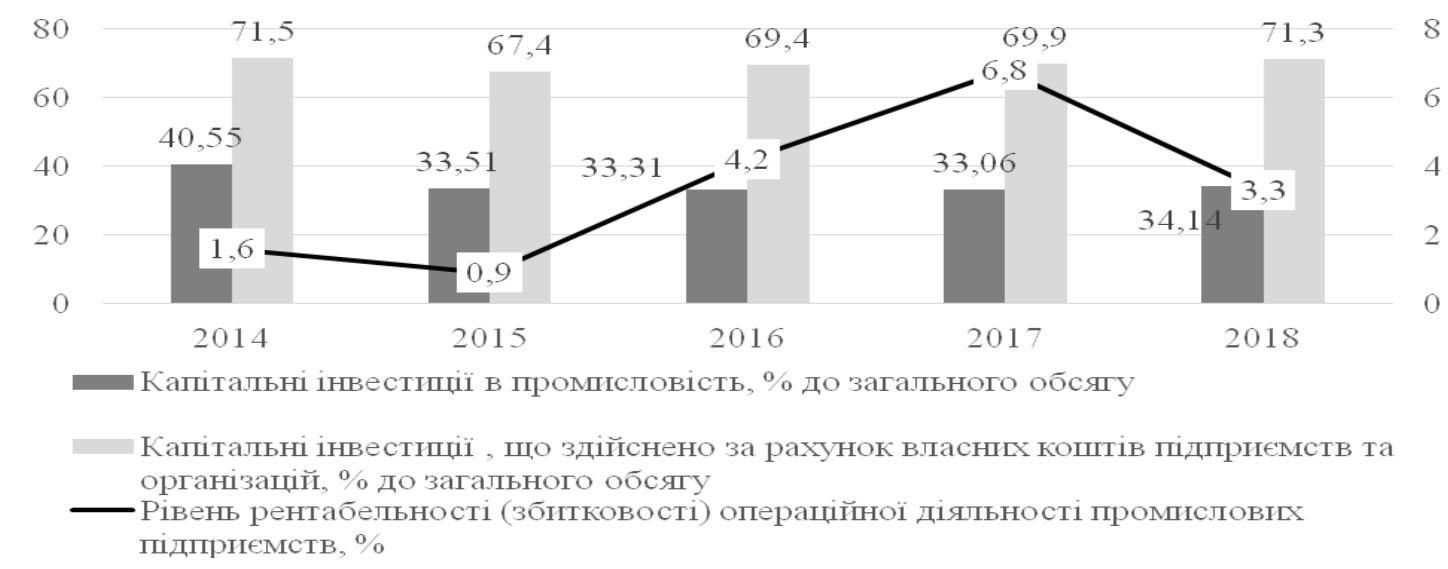

Рисунок 2. Аналіз капітальних інвестицій за видами економічної діяльності та джерелами фінансування [3; 4]

Тобто процеси інвестування у вітчизняній національній економіці потребують розробки дієвого механізму правового регулювання на макрорівні та управління на мікрорівні, який би задовольнив сучасні потреби ефективного господарювання. Інструментом, що забезпечує необхідні перетворення, виступає система страхування.

Страхування інвестицій, а саме його правове регулювання, позначається дієвим механізмом активізації та ефективного розвитку інвестиційної діяльності в Україні.

Аналіз останніх досліджень і публікацій. Глибину досліджень проблемних питань у сфері страхування інвестицій, зокрема правового регулювання, доводять численні наукові праці вітчизняних та зарубіжних авторів: Н. Б. Пацурія, I. М. Войцеховської, А. С. Головачової [5], $\quad$ В. І. Форманюка [6], Р. А. Калюжного, Л. В. Андрущенко, I. Г. Андрущенка [7], О. М. Вінник [8], Н. О. Гутаревич [9], Б. В. Деревянка [10], В. Д. Чернадчука [11] та багатьох інших. Не зменшуючи наукової та практичної значущості наукового набуття, $€$ необхідність у подальших дослідженнях порушеної наукової проблеми.

Формування мети статті. Таким чином, метою статті є надання рекомендацій щодо вдосконалення механізму правового регулювання страхування інвестицій в Україні, який, зі свого боку, сприятиме їхній активізації та зростанню ефективності.

Виклад основного матеріалу. Правові, економічні та соціальні умови інвестиційної діяльності в загальних рисах законодавчо врегульовані в Україні. Інвестиціями, згідно із Законом України «Про інвестиційну діяльність», є «всі види майнових та інтелектуальних цінностей, що вкладаються в об'єкти підприємницької та інших видів діяльності, в результаті якої створюється прибуток (доход) та/або досягається соціальний та екологічний ефект» [12]. 
Цінностями, які виступають засобом таких вкладів у грошовому вимірі можуть бути: грошові кошти та цінні папери окремих видів; рухоме та нерухоме майно; майнові права інтелектуальної власності; «ноу-хау»; права користування землею, водою, ресурсами, окремими об'єктами основних засобів; інші майнові права; інші цінності. Отже, інвестиційна діяльність є складним процесом взаємодії суб'єктів інвестиційної діяльності (громадян, юридичних осіб і держави) щодо впровадження інвестиційних проєктів відносно об'єктів інвестиційної діяльності, під час якого здійснюється досягнення цінностей і виконання завдань інноваційного розвитку національної економіки загалом та окремих виробництв, галузей, регіонів, секторів економіки. Капітальними є «інвестиції, що спрямовуються на створення (придбання), реконструкцію, технічне переоснащення основних засобів, очікуваний строк корисної експлуатації яких перевищує один рік» [12].

Важливість активізації інвестиційної діяльності для сучасного вітчизняного соціальноекономічного розвитку важко переоцінити, але іiі складність як фінансово-господарського процесу передбачає високу ймовірність виникнення необхідності у відшкодуванні збитків як фінансового показника, так і заподіяної шкоди технологічного, техногенного характеру тощо, що сформуються в результаті настання таких випадків (подій). Це врегульовано нормами права, а саме інвестиційним законодавством [12], спрямованим на забезпечення рівного захисту прав, інтересів і майна суб'єктів інвестиційної діяльності; страховим законодавством $[13 ; 14 ; 15]$, спрямованим на посилення страхового захисту майнових інтересів підприємств, установ, організацій та громадян. Тобто суб'єкти інвестиційної діяльності виступають або можуть виступати суб'єктами страхових правовідносин (рисунок 3), а страховий захист виступає фактором посилення активності суб'єктів правовідносин у напрямку здійснення інвестиційної діяльності.

Страховий (посилений) захист майнових інтересів суб'сктів

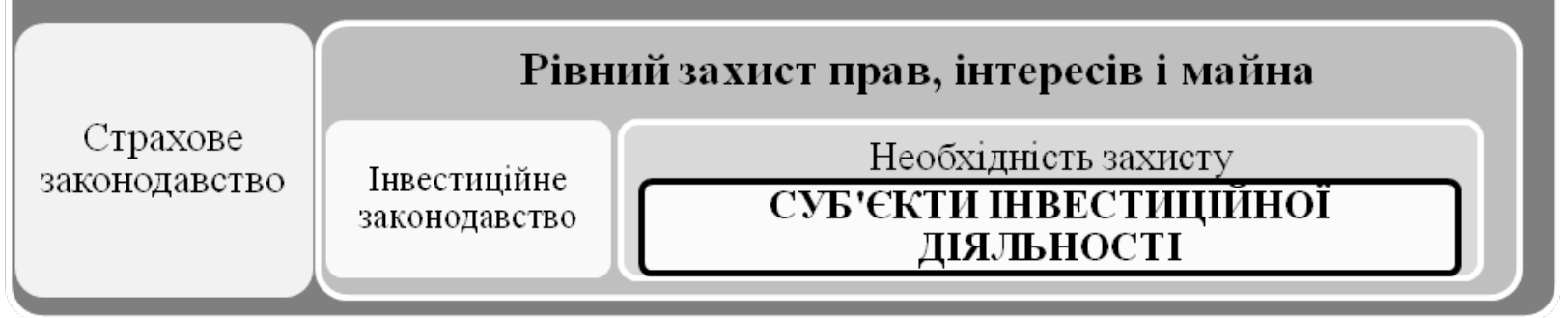

Рис. 3. Взаємозв'язок видів захисту суб'єктів інвестиційної діяльності

Страхування інвестицій на основі ЗУ «Про інвестиційну діяльність» належить до одного 3 видів добровільного страхування [12]. Із врахуванням того, що страхові платежі на основі Положення (стандарту) бухгалтерського обліку № 16 «Витрати» (далі - ПСБО 16 «Витрати») визнаються витратами операційної діяльності інвестора [16], з метою досягнення зростання ефективності господарювання інвестор оптимізує операційні витрати, у тому числі через їхню мінімізацію, 3 одного боку; але потреба в захисті економічних інтересів суб'єктів інвестиційних процесів та відшкодування збитків за результатами їхнього здійснення гостро існує в соціально-економічному масштабі на всіх рівнях національної економіки, 3 іншого. Зрозуміло, розв'язання наявної суперечливості закономірностей управлінського впливу на рівні суб'єктів господарювання неможливе без удосконалення системи їхнього правового регулювання, що пропонується саме в підсистемі правового регулювання процесів страхування.

Обов'язковий характер страхування, згідно із законодавством, має страхування «цивільної відповідальності інвестора, в тому числі за шкоду, заподіяну довкіллю, здоров’ю людей, за угодою про розподіл продукції, якщо інше не передбачено такою угодою» [12]. Згідно із Законом України «Про угоди про розподіл продукції», під продукцією мають на увазі «корисні копалини загальнодержавного та місцевого значення (мінеральна сировина), що видобуваються (виробляються) під час розробки родовищ корисних копалин» [17]. 
Отже, законодавство щодо страхування інвестицій сформовано так, що обов'язковість страхування передбачено лише для інвестиційних проєктів із видобування корисних копалин. Але капітальні інвестиції, які на основі наданих у статті досліджень гостро потребують удосконалення саме правового врегулювання, передбачають реалізацію інвестиційних проєктів і за іншими видами економічної діяльності з високим ступенем імовірності настання небажаних подій (будівництво, енергетика, транспорт, торгівля, сільське господарство тощо), що зумовлюють захист майнових інтересів фізичних i юридичних осіб та передбачають необхідність у їхньому страхуванні.

Дослідження на основі відомостей Державної служби статистики України демонструють, що тенденції стану й розвитку ринку страхування в Україні 3 видів страхування, інших, ніж страхування життя, неоднозначні [18] (рисунок 4).

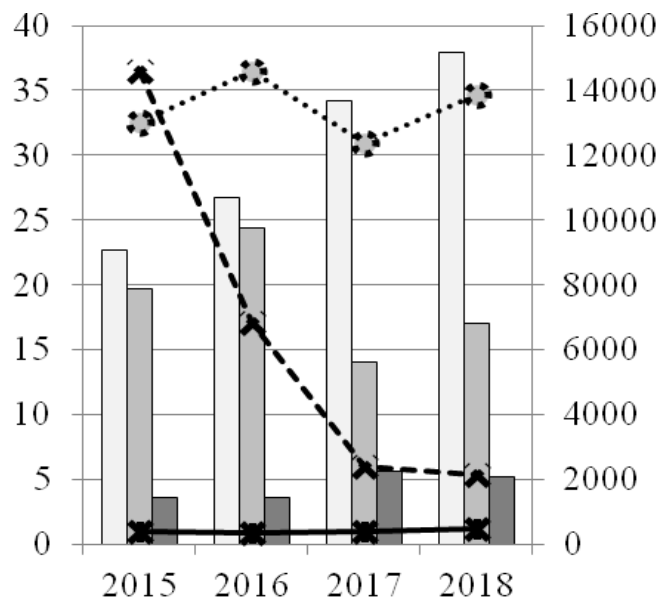

$\square$ Валові надходження страхових платежів (премій, внесків): усього / мЛн

$\square$ Валові надходження страховцх платежів (премій, внесків): страхування інвестищій

$\square$ Валові надходження страхових платежів (премій, внесків) страхування фінансових ризиків, МлН

- *- - Загальнй обсяг відповідальності: страхування інвестищій

відповідальності: страхування фінансових ризиків, млн

Показники розвитку добровільного страхування

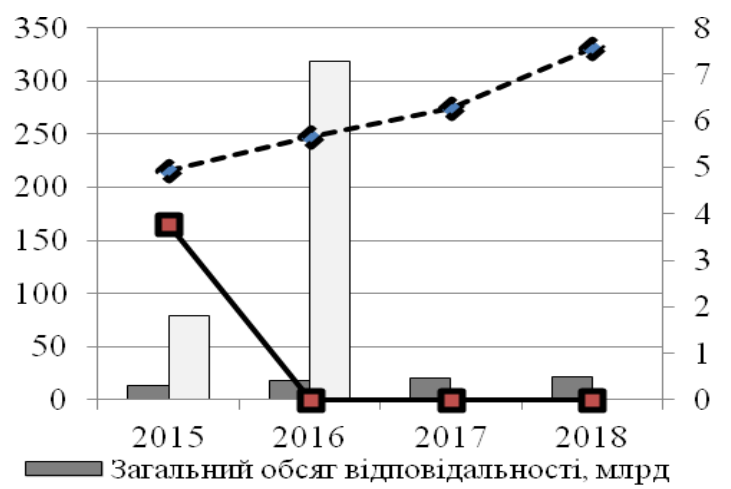

$\square$ Загальншй обся відповідальності: страхування цвільної відповідальності інвестора, у тому числі за шкоду, заподіяну довкіллю, здоров'ю людей, за угодою про розподіл продукціі, якщо інше не передбачено такою утодою, тис.

- - - Валові надходження страхових платежів (премій, внесків): усь ого, млн

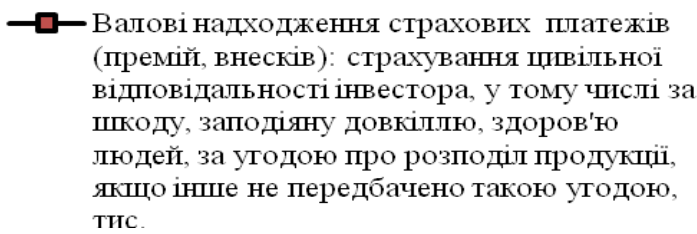

Показники розвитку обов'язкового страхування

Рис. 4. Стан і розвиток ринку України з видів страхування, інших, ніж страхування життя [18]

Так, за динамікою розвитку добровільного страхування спостерігається зростання валових надходжень страхових платежів, загальний обсяг відповідальності за добровільним страхуванням коливається, але його динаміка відносно стабільна. Виявлена тенденція демонструє проблеми ціноутворення на страхові послуги в Україні, зокрема неврахування в них інфляційних процесів. За видом «Страхування інвестицій» валові надходження страхових платежів зросли у 2016 році, порівняно з 2015 роком, але у 2018 році їхній рівень був меншим, 
порівняно 32016 роком, на 30,22\%; загальний обсяг відповідальності за цим видом страхування за досліджуваний період зменшився в 7 разів. Резонансність негативних тенденцій розвитку страхування інвестицій виявляється в тому, що вони обернено пропорційні обсягам інвестицій в Україні як прямих, так і капітальних, у яких негативні тенденції відсутні (рисунок 1).

До кола об'єктів, що досліджуються, включено страхування фінансових ризиків як опосередкований інструмент управління прямими інвестиціями. За цим видом страхування виявлено тенденції зростання як за категорією страхових надходжень, так і за обсягом відповідальності у 2017-2018 pp., порівняно 3 2015-2016 pp., що демонструє більш високий ступінь захищеності економічних інтересів суб' єктів правовідносин у сфері впровадження прямих інвестицій у вітчизняній національній економіці, на відміну від сфери капітальних інвестицій.

Відносно показників розвитку обов'язкового страхування в Україні, серед видів якого має місце страхування цивільної відповідальності інвестора, навіть за шкоду, заподіяну довкіллю, здоров'ю людей, за угодою про розподіл продукції, треба відмітити зростання тенденцій загального обсягу відповідальності та валових надходжень страхових платежів. Обернена (негативна) тенденція розвитку характеризує обов'язкове страхування цивільної відповідальності інвестора, яка у 2018 році призвела й до надходжень, і до відповідальності за цим видом страхування до нульових позицій. Отже, інвестиції у сфері видобування корисних копалин в Україні вичерпали себе, що, з одного боку, не суперечить світовим та вітчизняним стратегічним векторам розвитку, але, з іншого, призводить до випередження негативних темпів змін у національній економіці над позитивними.

Результати проведених досліджень сукупно підтверджують (доводять) сформульовану гіпотезу щодо страхування як дієвого інструменту підвищення ефективності та активізації інвестиційної діяльності, обгрунтуванням якої виступає розробка механізму правового регулювання страхування інвестицій в Україні (рисунок 5).

Механізм правового регулювання страхування інвестицій в Україні сформовано в розрізі двох основних видів інвестицій: прямих і капітальних. Запропонований механізм правового регулювання страхування інвестицій в Україні відрізняється від наявних саме в частині капітальних інвестицій, які за результатами проведених досліджень у статті найбільш потребують удосконалення їхнього правового регулювання на макроекономічному рівні. Здійснене розділення елементів механізму правового регулювання страхування інвестицій на прямі й капітальні передбачає необхідність змін у Законі України «Про страхування» (далі Закон). Логічно пункт 17 статті 6 цього Закону викласти в редакції «страхування прямих інвестицій» та додати до статті 7 цього Закону пункт «страхування капітальних інвестицій».

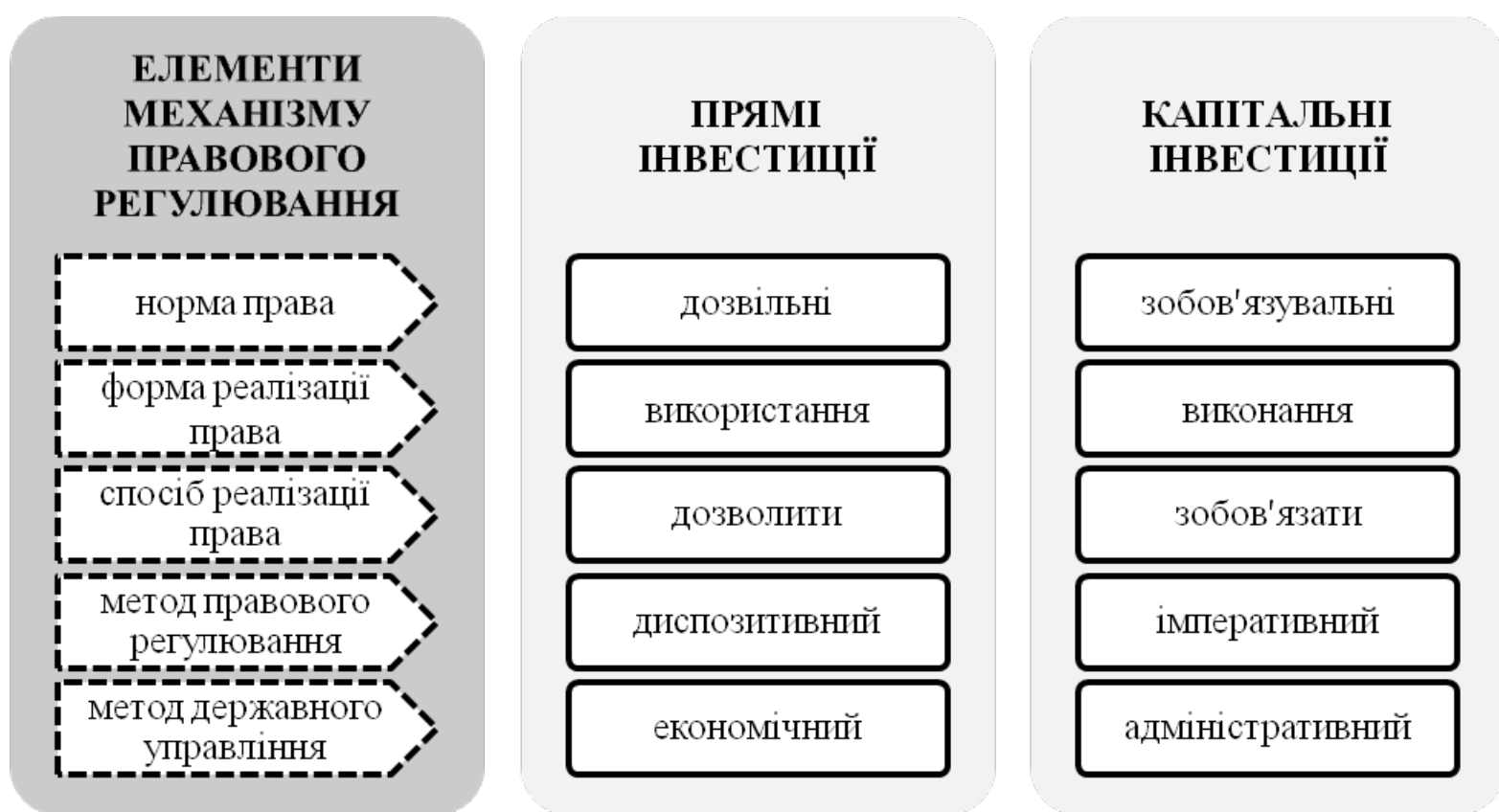

Рис. 5. Механізм правового регулювання страхування інвестицій в Украӥні $[19$, c. $4 ; 20$, c. 147] 
Застосування запропонованих нормативно-правових положень повинно ввести в дію сформований механізм правового регулювання страхування інвестицій в Україні, який сприятиме їхній активізації та зростанню ефективності.

Висновки. У результаті проведеного дослідження розроблено пропозиції стосовно вдосконалення чинного механізму правового регулювання страхування інвестицій в Україні, що здійснено шляхом диференціації та ідентифікації наявних в теорії держави й права елементів механізму правового регулювання загалом відносно прямих і капітальних інвестицій, залежно від дійсних тенденцій показників ефективності й розвитку кожного 3 видів інвестиційної діяльності. Відмінна ознака запропонованого механізму правового регулювання страхування інвестицій в Україні полягає в тому, що до страхування капітальних інвестицій застосовуються зобов'язувальні норми права, передбачається форма реалізації права - виконання, спосіб реалізації права - зобов'язання, метод правового регулювання імперативний, метод державного управління - адміністративний, що, зі свого боку, сприятиме активізації інноваційної діяльності в частині впровадження капітальних інвестицій та зростанню їхньої ефективності, з огляду на те, що через механізм страхування забезпечується соціально-економічна безпека всіх учасників цих господарських процесів та суб'єктів відповідних правовідносин.

Перспективою подальших досліджень виступає розробка проєкту інструкції (постанови) щодо здійснення обов'язкового страхування капітальних інвестицій, у якій повинні бути обгрунтовані норми (межі) страхових платежів, страхових відшкодувань тощо.

\section{Список використаних джерел}

1. Ц Цілі сталого розвитку: Україна. Національна доповідь 2017. Міністерство економічного розвитку і торгівлі України. URL : http://un.org.ua/images/SDGs_NationalReportUA_Web_1.pdf (дата звернення: 22.02.2020).

2. Прямі інвестиції (акціонерний капітал та боргові інструменти) в економіці України / 3 України (за періоди з початку року). URL : http://www.ukrstat.gov.ua (дата звернення: 12.02.2020).

3. Капітальні інвестиції за джерелами фінансування (щоквартальні показники). Капітальні інвестиції за видами економічної діяльності (щоквартальні показники). URL : http://www.ukrstat.gov.ua/operativ/menu/menu_u/ioz.htm (дата звернення: 05.02.2020).

4. Рентабельність операційної діяльності підприємств за видами економічної діяльності. URL : http://www.ukrstat.gov.ua/ (дата звернення: 25.02.2020).

5. Пацурія Н. Б., Войцеховська І. М., Головачова А. С. Правове регулювання діяльності у сфері страхування та перестрахування: проблеми теорії та практики : монографія. Київ : Видавництво Ліра-К, 2017. $256 \mathrm{c.}$

6. Форманюк В. І. Правове регулювання страхової діяльності в Україні. Часопис цивілістики. 2016. № 20. С. 100-102.

7. Калюжний Р. А., Андрущенко Л. В., Андрущенко І. Г. Державно-правове регулювання страхування у сфері зовнішньоекономічної діяльності. Київ : «МП Леся», 2012. 184 с.

8. Вінник О. М. Інвестиційне право : навч. посіб. Київ : Юрид. думка, 2005. 568 с.

9. Гутаревич Н. О. Правові форми інвестиційної діяльності в Україні [Текст] : автореф. дис. ... канд. юрид. наук : $\quad 12.00 .04 . \quad$ Приват. акціонер. тво "ВНЗ" Міжрегіон. акад. упр. персоналом". Київ, 2018. 20 с.

10. Деревянко Б. В. Правове регулювання інвестиційної та інноваційної діяльності : навч. посібник. МВС України, Донецький юридичний інститут. Донецьк : Видавничий дім «Кальміус», 2012. 204 с.

11. Чернадчук В. Д., Сухонос В. В., Чернадчук Т.О. Інвестиційне право України: навчальний посібник; за заг. ред. В. Д. Чернадчука. Суми : Університетська книга, 2001. 260 с.

12. Про інвестиційну діяльність : Закон України 1560-XII. URL : https://zakon.rada.gov.ua/laws/show/1560-12/ (дата звернення: 05.02.2020).

13. Господарський кодекс України : Закон України від 16 січня 2003 року № 436-IV. URL : https://zakon.rada.gov.ua/laws/show/436-15 (дата звернення: 08.02.2020).

14. Цивільний кодекс України : Закон України від 16 січня 2003 року № 435-IV. URL : https://zakon.rada.gov.ua/laws/show/435-15 (дата звернення: 02.03.2020). 
15. Про страхування : Закон України від 7 травня 1996 року № 85/96-ВР у редакції Закону від 4 жовтня 2001 року № 2745-III. URL : https://zakon.rada.gov.ua/laws/show/85/96-вр (дата звернення: 02.03.2020).

16. Положення (стандарт) бухгалтерського обліку № 16 «Витрати». Наказ Міністерства фінансів України від 1.12.1999 № 318. URL : https://buhgalter911.com/normativnaya-baza/instr-planrah/standart-buhgalterskogo/pologhennya-standart-buhgaltersykogo-1021482.html (дата звернення: 12.03.2020).

17. Про угоди про розподіл продукції. Закон України 1039-XIV. URL : https://zakon.rada.gov.ua/laws/show/1039-14 (дата звернення: 11.03.2020).

18. Інформація про стан $\mathrm{i}$ розвиток страхового ринку України. URL : https://www.nfp.gov.ua/ua/Informatsiia-pro-stan-i-rozvytok-strakhovoho-rynku-Ukrainy.html (дата звернення: 10.03.2020).

19. Бурик 3. М. Система методів державного регулювання сталого розвитку в Україні. Актуальні проблеми державного управління. 2016. № 1(49). С. 1-8. URL : http://www.kbuapa.kharkov.ua/e-book/apdu/2016-1/doc/2/03.pdf (дата звернення: 05.03.2020).

20. Скакун О. Ф. Теорія держави і права : підручник. Пер. з рос. Харків : Консул, 2001. $656 \mathrm{c}$.

\section{References}

1. Tsili staloho rozvytku: Ukraina. Natsionalna dopovid 2017. Ministerstvo ekonomichnoho rozvytku i torhivli Ukrainy [Sustainable Development Goals: Ukraine. Ministry of Economic Development and Trade of Ukraine]. http://un.org.ua/images/SDGs_NationalReportUA_Web_1.pdf [in Ukrainian].

2. Priami investytsii (aktsionernyi kapital ta borhovi instrumenty) $\mathrm{v}$ ekonomitsi Ukrainy/z Ukrainy (za periody z pochatku roku) [Direct investments (equity and debt instruments) in the economy of Ukraine / from Ukraine (from the beginning of the year)]. URL : http://www.ukrstat.gov.ua [in Ukrainian].

3. Kapitalni investytsii za dzherelamy finansuvannia (shchokvartalni pokaznyky). Kapitalni investytsii za vydamy ekonomichnoi diialnosti (shchokvartalni pokaznyky) [Capital investments by sources of funding (quarterly indicators). Capital investment by type of economic activity (quarterly indicators)]. URL : http://www.ukrstat.gov.ua/operativ/menu/menu_u/ioz.htm [in Ukrainian].

4. Rentabelnist operatsiinoi diialnosti pidpryiemstv za vydamy ekonomichnoi diialnosti [Profitability of operating activities of enterprises by type of economic activity]. URL : http://www.ukrstat.gov.ua/ [in Ukrainian].

5. Patsuriia, N. B., Voitsekhovska, I. M., Holovachova, A. S. (2017). Pravove rehuliuvannia diialnosti u sferi strakhuvannia ta perestrakhuvannia: problemy teorii ta praktyky : monohrafiia [Legal regulation of activity in the field of insurance and reinsurance: problems of theory and practice : monograph]. Kyiv : Vydavnytstvo Lira-K. 256 s. [in Ukrainian].

6. Formaniuk, V. I. (2016). Pravove rehuliuvannia strakhovoi diialnosti v Ukraini. Chasopys tsyvilistyky [Legal regulation of insurance activity in Ukraine. Journal of Civil Studies]. № 20. S. 100102 [in Ukrainian].

7. Kaliuzhnyi, R. A., Andrushchenko, L. V., Andrushchenko, I. H. (2012). Derzhavno-pravove rehuliuvannia strakhuvannia u sferi zovnishnoekonomichnoi diialnosti [State legal regulation of insurance in the sphere of foreign economic activity]. Kyiv : MP Lesya. 184 s. [in Ukrainian].

8. Vinnyk, O. M. (2005). Investytsiine pravo : navch. posib. [Investment Law: Educ. tool.]. Kyiv : Yuryd. Dumka. 568 s. [in Ukrainian].

9. Hutarevych, N. O. (2018). Pravovi formy investytsiinoi diialnosti v Ukraini [Tekst] : avtoref. dys. ... kand. yuryd. nauk : 12.00.04. Pryvat. aktsioner. t-vo "VNZ "Mizhrehion. Akad. upr. personalom" [Legal Forms of Investment Activity in Ukraine [Text] : abstract. diss. ... Cand. lawyer. Sciences: 12.00.04. Private. shareholder. constituency "Higher education institution" Interregion. Acad. ref. staff."]. Kyiv. 20 s. [in Ukrainian].

10. Derevianko, B. V. (2012). Pravove rehuliuvannia investytsiinoi ta innovatsiinoi diialnosti : navch. posibnyk. MVS Ukrainy, Donetskyi yurydychnyi instytut [Legal regulation of investment and innovation activity : textbook. Manual. Ministry of Internal Affairs of Ukraine, Donetsk Law Institute]. Donetsk : Vydavnychyi dim «Kalmius». 204 s. [in Ukrainian]. 
11. Chernadchuk, V. D., Sukhonos, V. V., Chernadchuk, T. O. (2001). Investytsiine pravo Ukrainy : navchalnyi posibnyk [Investment Law of Ukraine : tutorial; for the General. ed. V. D. Chernachuk]. Sumy : Universytetska knyha. 260 s. [in Ukrainian].

12. Pro investytsiinu diialnist : Zakon Ukrainy 1560-XII [About investment activity : Law of Ukraine 1560-XII]. URL : https://zakon.rada.gov.ua/laws/show/1560-12/ [in Ukrainian].

13. Hospodarskyi kodeks Ukrainy : Zakon Ukrainy vid 16 sichnia 2003 roku № 436-IV [Economic Code of Ukraine: Law of Ukraine of January 16, 2003 No. 436-IV]. URL : https://zakon.rada.gov.ua/laws/show/436-15 [in Ukrainian].

14. Tsyvilnyi kodeks Ukrainy : Zakon Ukrainy vid 16 sichnia 2003 roku № 435-IV [Civil Code of Ukraine: Law of Ukraine of January 16, 2003 No. 435-IV]. URL : https://zakon.rada.gov.ua/laws/show/435-15 [in Ukrainian].

15. Pro strakhuvannia : Zakon Ukrainy vid 7 travnia 1996 roku № 85/96-VR u redaktsii Zakonu vid 4 zhovtnia 2001 roku № 2745-III [On Insurance : Law of Ukraine of May 7, 1996 No. 85/96-BP as amended by the Law of October 4, 2001 No. 2745-III]. URL : https://zakon.rada.gov.ua/laws/show/85/96-vr [in Ukrainian].

16. Polozhennia (Standart) bukhhalterskoho obliku № 16 «Vytraty». Nakaz Ministerstva finansiv Ukrainy vid 1.12.1999 № 318 [Regulation (Standard) of accounting No. 16 "Expenses". Order of the Ministry of Finance of Ukraine dated 31.12.1999 № 318]. URL : https://buhgalter911.com/normativnayabaza/instr-plan-rah/standart-buhgalterskogo/pologhennya-standart-buhgaltersykogo-1021482.html [in Ukrainian].

17. Pro uhody pro rozpodil produktsii. Zakon Ukrainy 1039-XIV [About production sharing agreements. Law of Ukraine 1039-XIV]. URL : https://zakon.rada.gov.ua/laws/show/1039-14 [in Ukrainian].

18. Informatsiia pro stan i rozvytok strakhovoho rynku Ukrainy [Information on the state and development of the Ukrainian insurance market]. URL : https://www.nfp.gov.ua/ua/Informatsiia-pro-stani-rozvytok-strakhovoho-rynku-Ukrainy.html [in Ukrainian].

19. Buryk, Z. M. (2016). Systema metodiv derzhavnoho rehuliuvannia staloho rozvytku v Ukraini. Aktualni problemy derzhavnoho upravlinnia [System of methods of state regulation of sustainable development in Ukraine. Actual problems of public administration]. 1(49). S. 1-8. URL : http://www.kbuapa.kharkov.ua/e-book/apdu/2016-1/doc/2/03.pdf [in Ukrainian].

20. Skakun, O. F. (2001). Teoriia derzhavy i prava : pidruchnyk. [State and Law Theory : a textbook]. Per. z ros. Kharkiv : Konsul. 656 s. [in Ukrainian].

Rozhenko Oleksandra,

$\mathrm{PhD}$ in Economic sciences

(Donetsk Law Institute, MIA of Ukraine, Kryvyi Rih)

ORCID: https://orcid.org/0000-0002-9358-5436

\section{LEGAL REGULATION OF INVESTMENT INSURANCE IN UKRAINE}

The article investigates the trends of investment activity in Ukraine through: studying the dynamics of direct and capital investments in the economy of Ukraine during 2014-2018, insurance (enhanced) protection of entities' property interests, namely volumes thereof in monetary terms and rates of change in percentage terms; analysis of capital investments by types of economic activity and sources of funding, namely their percentage share in the total amount, their percentage share due to own funds of companies and organizations, the percentage level of operating profitability (unprofitability) of industrial companies. An interrelation between the types of protection of investment activity entities has been established. The investment law provides equal protection of the rights, interests and property of investment entities, while the insurance law. An analysis of the status and the development of the Ukrainian market by types of insurance other than life insurance has been conducted, while the following indicators of the volume of voluntary and compulsory insurance have been used: gross receipts of insurance payments (premiums, contributions) and the total amount of liabilities in absolute monetary terms. The scientific article has formulated and proved the hypothesis that insurance is an effective tool for improving the efficiency and stepping up the investment activity in Ukraine. An improvement of the mechanism for the legal regulation of investment insurance in Ukraine in terms of direct and capital investments has been proposed, which includes the following legal regulation elements, respectively: the discretionary and imperative provisions of the law, the forms of implementing the law - the use and the enforcement, the method of implementing the law - to allow and to oblige, the method of legal regulation - the discretionary and imperative one, the method of public administration - the economic and administrative one. Proposals have been made to amend the Law of Ukraine "On Insurance".

Key words: insurance; legal regulation; investments; efficiency; development dynamics; mechanism.

Надійшла до редколегії 20.03.2020 